Article

\title{
Evaluating the Influence of Rain Event Characteristics on Rainfall Interception by Urban Trees Using Multiple Correspondence Analysis
}

\author{
Katarina Zabret $@$ and Mojca Šraj * \\ Faculty of Civil and Geodetic Engineering, University of Ljubljana, Jamova 2, SI-1000 Ljubljana, Slovenia; \\ katarina.zabret@fgg.uni-lj.si \\ * Correspondence: mojca.sraj@fgg.uni-lj.si
}

Received: 29 November 2019; Accepted: 16 December 2019; Published: 17 December 2019

\begin{abstract}
Urban trees play an important role in the built environment, reducing the rainfall reaching the ground by rainfall interception. The amount of intercepted rainfall depends on the meteorological and vegetation characteristics. By applying the multiple correspondence analysis (MCA), we analysed the influence of rainfall amount, intensity and duration, the number of raindrops, the mean volume diameter (MVD), wind speed and direction on rainfall interception. The analysis was based on data from 176 events collected over more than three years of observations. Measurements were taken under birch (Betula pendula Roth.) and pine (Pinus nigra Arnold) trees located in an urban park in the city of Ljubljana, Slovenia. The results indicate that rainfall interception is influenced the most by rainfall amount and the number of raindrops. In general, the ratio of rainfall interception to gross rainfall decreases with longer and more intense rainfall events. The influence of the raindrop number depends also on their size (MVD), which is evident especially for the pine tree. For example, pine tree interception increases with smaller raindrops regardless of their number. In addition, MCA gives a new insight into the influence of wind characteristics, which was not visible using previous methods of data analysis (regression analysis, correlation matrices, regression trees, boosted regression trees). According to the nearby buildings, a wind corridor is sometimes created, decreasing rainfall interception by both tree species.
\end{abstract}

Keywords: rainfall interception; throughfall; multiple correspondence analysis (MCA); rainfall event characteristics; urban trees

\section{Introduction}

For decades, trees have been recognised as an important element of the ecohydrological cycle due to rainfall partitioning [1,2]. Rainfall $(\mathrm{P})$, falling above the canopies, does not directly reach the ground, as it is divided into three components, namely throughfall (TF), stemflow (SF), and interception (I) [3]. Throughfall describes the amount of rainfall reaching the ground underneath the tree by falling through the gaps in canopy or dripping from the leaves and branches $[3,4]$. Stemflow is part of the rainfall initially intercepted by the canopy but later reaching the ground as a concentrated flux flowing down the branches and stem [5]. The remaining rainfall never reaches the ground as it is intercepted by the canopy and eventually evaporates back into the atmosphere. The latter component of rainfall partitioning has been recently recognised to significantly help in managing stormwater runoff in urban areas [6-9]. With urban development, the hydrological properties of an area are considerably changed as vegetation is removed, infiltration is decreased due to the introduction of impervious surfaces, the subsurface flow shifts to a surface one, storm water runoff increases, has a faster response and a higher peak $[8,10,11]$. 
Rainfall partitioning in urban areas has been recently addressed in various studies involving field measurements or introducing different hydrological and interception models of an area. For example, measurements of rainfall interception were performed in California under pear and cork oak trees, which intercepted $15 \%$ and $27 \%$ of rainfall, respectively [12]. Asadian et al. [13] conducted measurements under western red cedars and Douglas-firs in an urban area of Vancouver, Canada, and reported $61 \%$ and $49 \%$ of rainfall interception, respectively. Furthermore, Livesley et al. [7] performed measurements under Eucalyptus nicholii and Eucalyptus saligna trees in Melbourne, Australia, and reported $44 \%$ and $29 \%$ of rainfall interception, respectively. Yang et al. [8] conducted measurements under Sophora japonica, Ginkgo biloba, Zelkova serrata and Aesculus turbinate in Seoul, South Korea, with a mean interception rate of $35.8 \%, 57.9 \%, 20.6 \%$, and $30.6 \%$, respectively. Measurements performed in an urban area of Ljubljana, Slovenia, demonstrated $23 \%$ and $47 \%$ of rainfall interception by birch and pine trees, respectively [14]. Furthermore, Armson et al. [15] demonstrated a reduction of runoff by $62 \%$ due to rainfall interception of maple trees in Manchester, UK. For the modelling of rainfall interception, the UFORE-Hydro model was used in Baltimore, Maryland, showing that an increase of tree coverage above an impervious cover of up to $40 \%$ decreased the runoff by $3.4 \%$ [16]. Similarly, modelling using the Stormwater Management Calculator showed that the runoff from a parking lot in Ljubljana, Slovenia, could decrease up to $7.3 \%$ by covering $10 \%$ of the area with trees [9]. The SCS-CN method was applied in southern Sweden resulting in a $1-5 \%$ runoff reduction [17]. For the case of Vancouver, Canada, the interception of the trees in an urban area was estimated with a new analytical model and corresponded well to the values measured by Armson et al. $[15,18]$. For the case of Seoul, South Korea, the measured interception was compared to the results of interception models by Gash and Rutter as well to the WetSpa model, which was eventually also recommended for further estimation of tree influence [19].

The amount of intercepted rainfall is influenced by different variables, generally divided into meteorological and vegetation ones [20]. Meteorological variables describe the characteristics of a rainfall event such as the amount of rainfall, duration and intensity [12,21-23], wind speed and direction $[24,25]$, air temperature and humidity [9,26], raindrop size, velocity and the number of raindrops $[4,14,27]$. Vegetation variables, on the other hand describe the properties of the trees, for example, tree height, projected area of the canopy, diameter at the breast height, leaf area index, canopy openness, branch inclination and phenoseasons [8,28-31]. Due to the co-dependence of the variables, researchers use different approaches to analyse their influence. The most commonly used methods are regression analysis [15,31-33], multiple regression analysis [21,25,34] and the correlations matrix $[9,35,36]$. However, to be able to estimate the mutual influence of more than one variable, more complex statistical and data mining techniques were introduced, such as regression trees [14,24], generalized boosted regression trees [14,37-39], principal component analysis [30] and multiple correspondence analysis [40].

However, analyses of the influence of different variables on rainfall partitioning by urban trees are quite rare $[8,9,14]$. The values of the variables are expected to differ among natural and urban stands $[6,9,13]$. In forests and plantations, trees grow on continuous surfaces, which can alter wind speed and direction, air temperature and humidity. Additionally, when trees grow in groups they have less space to develop the canopy, and the light source comes mainly from above, which means that trees in stands, unlike single trees, struggle for the best growing conditions.

Multiple correspondence analysis (MCA) is an extension of the correspondence analysis (CA), and has been rarely used in hydrology. It has been mainly applied to questionnaire data [41-43] and data in medicine [44-46]. However, Van Stan et al. [40] applied multiple correspondence analysis for throughfall data from southern live oak forest in Georgia, USA. It was used to identify interacting storm conditions (median intensity, median absolute deviation (MAD) of intensity, median wind-driven droplet inclination angle, and MAD of wind speed) corresponding to temporal concentration in relative throughfall beyond the $73 \%$ which corresponds to the observed median value. In order to evaluate the influence of rain event characteristics on rainfall interception by 
birch and pine trees, a detailed analysis using MCA was performed in this study. The main objectives of the presented study are as follows: (i) implementation of the MCA to a set of data on rainfall interception in an urban area, (ii) showing how we can upgrade the statistical analysis allowing us to find the new connections and information in the collected data, and (iii) pointing out the co-dependence between the influencing variables.

\section{Materials and Methods}

\subsection{Study Site}

The experimental plot is situated in a small urban park in the city of Ljubljana, Slovenia $\left(46.04^{\circ} \mathrm{N}\right.$, $14.49^{\circ} \mathrm{E} ; 292 \mathrm{~m}$ a.s.l.). On the edge of the park, there are parking lots on the north and east side and two-story $(14.5 \mathrm{~m}$ ) buildings on the west and south side (Figure 1). The climate has well defined seasons, influenced by maritime effects from the Mediterranean and subcontinental effects from the Pannonian Plain. The mean long-term (1986-2016) temperature is $11^{\circ} \mathrm{C}$ and the total annual rainfall is $1380 \mathrm{~mm}$. The average monthly temperature ranges between $-3{ }^{\circ} \mathrm{C}$ in winter and $24^{\circ} \mathrm{C}$ in summer. Autumn is the wettest season, with the most rainfall delivered, with a mean monthly value reaching up to $146 \mathrm{~mm}$ [47].

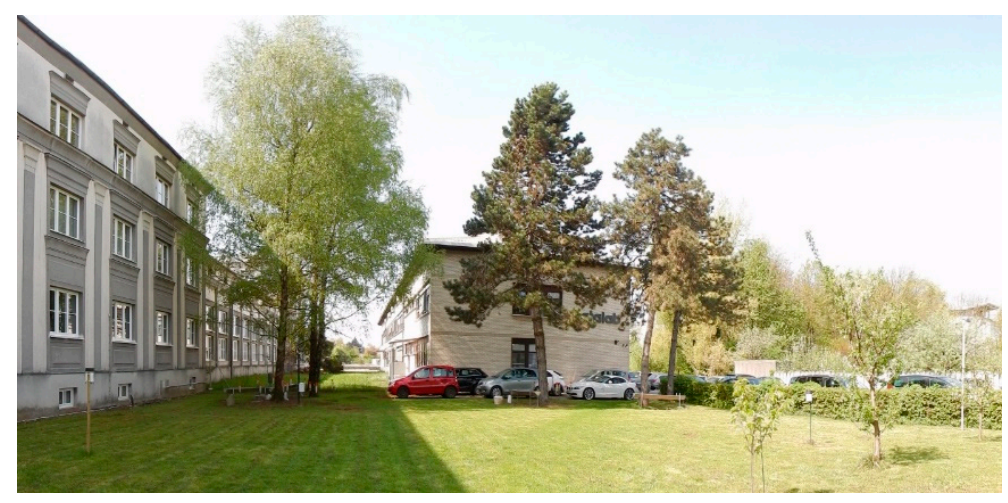

Figure 1. Study plot.

The experimental plot extends over an area of $600 \mathrm{~m}^{2}$. The observed trees are located in the western part of the plot, whereas the rest of it is characterised as a clearing, covered only with low grass (Figure 1). Measurements were conducted under two birch (Betula pendula Roth.) and two pine (Pinus nigra Arnold) trees. For the considered trees, various vegetation characteristics were determined. Pine trees are $12.0 \mathrm{~m}$ and $13.1 \mathrm{~m}$ high, have an average branch inclination of $95.2^{\circ}$ and $99.8^{\circ}$, projected crown areas of $7.0 \mathrm{~m}^{2}$ and $15.7 \mathrm{~m}^{2}$, and a diameter at breast height (DBH) of $16.7 \mathrm{~cm}$ and $21.3 \mathrm{~cm}$, respectively. The bark is rough with a storage capacity of $3.5 \mathrm{~mm}$ [48], the canopy coverage is on average $87.6 \%$, and the leaf area index is 3.9 (LAI-2200 plant canopy analyser, Li-Cor Inc.). Birch trees are $14.6 \mathrm{~m}$ and $16.7 \mathrm{~m}$ high, have an average branch inclination of $49.8^{\circ}$ and $53.3^{\circ}$, projected crown areas of $21.9 \mathrm{~m}^{2}$ and $20.3 \mathrm{~m}^{2}$, and a diameter at breast height (DBH) of $17.5 \mathrm{~cm}$ and $18.3 \mathrm{~cm}$, respectively. The bark is smooth with a storage capacity of $0.7 \mathrm{~mm}$ [48]. Four phenoseasons were determined for birch trees (leafing, leafed, leaf-fall and leafless). The canopy coverage during the full-leafed phenoseason is, on average, $78.3 \%$, and the leaf area index is 2.6 (LAI-2200 plant canopy analyser, Li-Cor Inc., Lincoln, NE, USA).

\subsection{Measurements}

The study plot is equipped with measurement devices to follow throughfall and stemflow under both tree species, as well as rainfall amount and its characteristics (drop size, velocity and amount) in the open. The data have been collected from the beginning of 2014. We have included three and a half years of measurements (from January 2014 to July 2017) in the analysis. 
In order to encompass throughfall's spatial variability, it was measured with through and funnel-type gauges. Under each tree, a steel through gauge $\left(0.75 \mathrm{~m}^{2}\right)$ was placed from the tree trunk towards the edge of the canopy. Two through gauges, one under a birch and one under a pine tree, were connected to a tipping bucket flow gauge (Unidata 6506G; $50 \mathrm{~mL} / \mathrm{tip}$ ) with an automatic data logger (Onset HOBO Event). From another two through gauges, throughfall was collected in polyethylene containers $(10+50 \mathrm{~L})$, manually gathered after each event. At the same time, the values of throughfall, collected with ten roving funnel-type gauges $\left(78.5 \mathrm{~cm}^{2}\right)$ under each tree species, were sampled. Stemflow was measured using a halved rubber hose, spirally wrapped around the stem. In case of the pine trees, it was routed to the $1.5 \mathrm{~L}$ container, emptied after each event, whereas, in the case of a birch tree, it was connected to a tipping bucket (Onset RG2-M, $0.2 \mathrm{~mm} / \mathrm{tip}$ ) with an automatic data logger (Onset HOBO Event).

The rainfall amount was measured on the clearing in the east part of the study plot. The tipping bucket $(0.2 \mathrm{~mm} /$ tip) rain gauge (Onset RG2-M) with an automatic data logger (Onset HOBO Event) was positioned $1 \mathrm{~m}$ above the ground and approximately $10 \mathrm{~m}$ from the nearest tree. Rainfall events were separated by dry periods of at least $4 \mathrm{~h}[9,14]$. Rainfall characteristics, such as drop size, velocity and the number of raindrops were measured with optical disdrometer (OTT Parsivel), which was located at the rooftop of the building on the south part of the study plot at the height of $14.5 \mathrm{~m}, 50 \mathrm{~m}$ from the nearest tree. The data of additional meteorological variables (wind speed and direction) were obtained from the nearest Slovenian Environment Agency's meteorological station Ljubljana-Bežigrad $\left(45.13^{\circ} \mathrm{N}, 14.52^{\circ} \mathrm{E} ; 299\right.$ m a.s.l.).

\subsection{Data Analysis Methods}

For the analysis of the influence of rain event characteristics, rainfall interception (I) was calculated from measured gross precipitation (P), throughfall (TF) and stemflow (SF) [14]:

$$
\mathrm{I}=\mathrm{P}-\mathrm{TF}-\mathrm{SF}
$$

The events were filtered prior the analysis due to clogging of the gauges during leaf fall or freezing. Snow events were excluded from the analysis. Rainfall interception was considered as a ratio between rainfall interception amount and the amount of gross rainfall (I/P).

Raw data, collected using a disdrometer, are assigned to one of the 1024 classes each minute. Classes consist of various combinations of the drop diameter (between 0.312 and $24.5 \mathrm{~mm}$ ) and velocity (between 0.05 and $20.8 \mathrm{~m} / \mathrm{s}$ ). From the collected data, the median volume diameter (MVD) as a measure of drop size was additionally calculated. MVD refers to the size of the drops, for which half of the volume of the rainfall smaller in drops, and half of the volume is larger in drops, than the mean [49].

The influence of rain event characteristics on rainfall interception was analysed using the multiple correspondence analysis (MCA). MCA is a multivariate statistical method used analogue to the principal component analysis (PCA) for descriptive rather than quantitative variables. MCA can be used to estimate relationships between the variables, characterize the individuals using the variables by linking them together, and study the similarities between the individuals in multidimensional space [42]. The similarity between the individuals is described by the distance between them, which is calculated using the chi-square distance. It is expressed as reduction of inertia $\chi^{2} / n$, where $\chi^{2}$ is the value of chi-squared test of independent variables and $n$ is the number of the expected values [42]. Therefore, dimensions show the statistical inertia of a variable. The number of the dimensions taken into account in the analysis can be selected using inertia-based scree plots or the "rule of 1" [50]. Due to a high-dimensional space, the cloud of the individuals cannot be visualized directly. By maximizing the projected inertia, they are projected into lower dimensions. The quality of this fit is measured by the percentage of inertia for each axis (ratio between the variability, explained by the map and the total variability) [42]. Results of the MCA are presented on diagrams. The dimensions are perpendicular to each other and independent, therefore each dimension has to be analyzed on its 
own. Dimensions are separated with lines, which can be interpreted as coordinate axes when dealing with two dimensions. The proximity of the variables and their location according to the axes show their interdependence. Shorter distances between the variables indicate a higher correspondence. Additionally, variables located in the same domain (positive or negative, i.e., with the same sign) are connected positively $[40,42,50]$.

MCA was performed using the R package MASS [51] included in the R software [52]. As event characteristics, we have taken into account the precipitation amount $(\mathrm{Pa})$, duration $(\mathrm{Pd})$ and intensity $(\mathrm{Pi})$, wind speed $(\mathrm{Ws})$ and direction $(\mathrm{Wd})$, raindrop size (MVD) and the number of raindrops $(\mathrm{NrD})$. The number of variables included in the MCA was reduced compared to the previous analyses using regression trees and boosted regression trees [14]. The variables, which in previous analyses have shown less impact on rainfall partitioning process (air temperature, relative humidity, duration of dry period, and day or night time of the event occurrence), were excluded from the MCA analysis. Furthermore, the initial MCA analysis also included the raindrop diameter and its velocity, but these variables did not make any contribution to the explanation of the process. Therefore, the properties of raindrops were described with MVD and $\mathrm{NrD}$.

The numerical values of the variables were transformed into descriptive ones according to the threshold values (Table 1). Threshold values of rainfall interception ratio to gross rainfall (I/P) were defined as median values, i.e., $36 \%$ in case of birch tree (IB36) and $75 \%$ in case of pine tree (IP75). The threshold values of event characteristics were initially also set as median values of the sample and were then adjusted through the sensitivity analysis to capture the highest inertia of two dimensions (Table 2). We used acronyms consisting of the variable, its threshold value and its range in the MCA (Table 1). The analysis was divided into three parts, enabling us to take a closer look at the influence of rainfall characteristics $(\mathrm{Pa}, \mathrm{Pd}, \mathrm{Pi})$, wind characteristics $(\mathrm{Wd}, \mathrm{Ws})$, and raindrop characteristics (MVD, NrD).

Table 1. Used acronyms of variables in MCA.

\begin{tabular}{cccc}
\hline Variable's Acronym & Threshold Value & Less than Threshold & More than Threshold \\
\hline Rainfall amount-Pa & $6 \mathrm{~mm}$ & Pa6:0 & Pa6:1 \\
Rainfall duration-Pd & $4 \mathrm{~h}$ & $\mathrm{Pd} 4: 0$ & $\mathrm{Pd} 4: 1$ \\
Rainfall intensity-Pi & $1.8 \mathrm{~mm} / \mathrm{h}$ & $\mathrm{Pi} 1.8: 0$ & Pi1.8:1 \\
Wind speed-Ws & $1.3 \mathrm{~m} / \mathrm{s}$ & Ws1.3:0 & Ws1.3:1 \\
Wind direction-Wd & $\mathrm{S}, \mathrm{N}, \mathrm{E}, \mathrm{W}, \mathrm{SE}, \mathrm{NE}, \mathrm{SW}, \mathrm{NW}$ & WdS/WdN/WdE/WdW/WdSE/WdNE/WdSW/WdNW \\
$\begin{array}{l}\text { Median volume } \\
\text { diameter-MVD }\end{array}$ & $1.5 \mathrm{~mm}$ & $\mathrm{MVD} 1.5: 0$ & $\mathrm{MVD} 1.5: 1$ \\
$\quad \begin{array}{l}\text { Number of } \\
\text { raindrops-NrD }\end{array}$ & $10,000 / 50,000 / 100,000$ & $\mathrm{NrD} 10: 0 / \mathrm{NrD} 10-50 / \mathrm{NrD} 50-100 / \mathrm{NrD} 100: 1$ \\
\hline
\end{tabular}

Table 2. Threshold values of variables, considered for MCA. The bold values are the selected ones.

\begin{tabular}{cccccc}
\hline $\mathbf{P a}(\mathbf{m m})$ & $\mathbf{P d}(\mathbf{h})$ & $\mathbf{P i}(\mathbf{m m} / \mathbf{h})$ & $\mathbf{W s} \mathbf{( m / s )}$ & $\mathbf{M V D}(\mathbf{m m})$ & $\mathbf{N r D}$ \\
\hline 6 & 1.5 & 0.8 & 0.5 & 1 & 10,000 \\
8 & 3 & 1.2 & 1 & 1.3 & 30,000 \\
10 & 4 & 1.4 & 1.3 & 1.5 & 50,000 \\
12 & 5.5 & 1.8 & 1.8 & 1.8 & $10,000,100,000$ \\
14 & 8 & 2.2 & 2 & 2 & $10,000,50,000,100,000$ \\
\hline
\end{tabular}

\section{Results and Discussion}

\subsection{Rainfall Event Characteristics, Rainfall Interception, Throughfall, and Stemflow}

In the measurement period from 1 January 2014 to 30 June 2017, in total, $4110 \mathrm{~mm}$ of rainfall was delivered during 413 events. Due to technical problems with the disdrometer, only 176 events with available complete data were considered for the analysis. The selected rainfall events accounted for $2050 \mathrm{~mm}$ of rainfall, with an average intensity of $2.8 \mathrm{~mm} / \mathrm{h}( \pm 6.4 \mathrm{~mm} / \mathrm{h})$ and an average duration of $8.3 \mathrm{~h}$ 
$( \pm 10.6 \mathrm{~h})$. The average drop velocity per event ranged from 1.6 to $5.3 \mathrm{~m} / \mathrm{s}$, while the average raindrop diameter per event ranged between 0.4 and $1.5 \mathrm{~mm}$. The smallest number of raindrops equal to 876 was detected during a short, $26 \mathrm{~min}$ long event, delivering only $6 \mathrm{~mm}$ of rainfall. However, the largest number of raindrops $(727,793)$ occurred during the longest observed event $(67 \mathrm{~h})$, delivering $84.4 \mathrm{~mm}$ of rainfall.

Throughfall under the birch tree accounted for $73 \%$ of gross rainfall, whereas, on average, per event it was equal to $59 \%( \pm 29 \%)$. Interestingly, for two events this exceeded the amount of rainfall in the open and reached values of $104 \%$ and $106 \%$ [14]. Stemflow was detected for 110 events in the case of the birch tree, ranging between $0.01 \%$ and $11.6 \%$. Regarding the total measured rainfall in the open, stemflow accounted for 3.3\%. Throughfall under the pine tree resulted in $53 \%$ of the gross rainfall and was, on average, equal to $32 \%( \pm 25 \%)$ per event. The highest throughfall reached up to $97 \%$. Stemflow for the pine tree was observed during 83 events, with an average value of $0.02 \%$ $( \pm 0.05 \%)$. In total, it accounted for $1.6 \mathrm{~mm}$ of rainfall, which corresponds to $0.06 \%$ of gross rainfall. For 12 events, the birch tree intercepted all of the rainfall in the open, whereas the interception ratio was lower than $10 \%$ during 16 events (Figure 2). In total, the rainfall interception by the birch tree was equal to $23.7 \%$. The pine tree intercepted $46.9 \%$ of the total rainfall. All of the rainfall was intercepted during 30 events, whereas only two events resulted in interception ratios lower than 10\% (Figure 2).
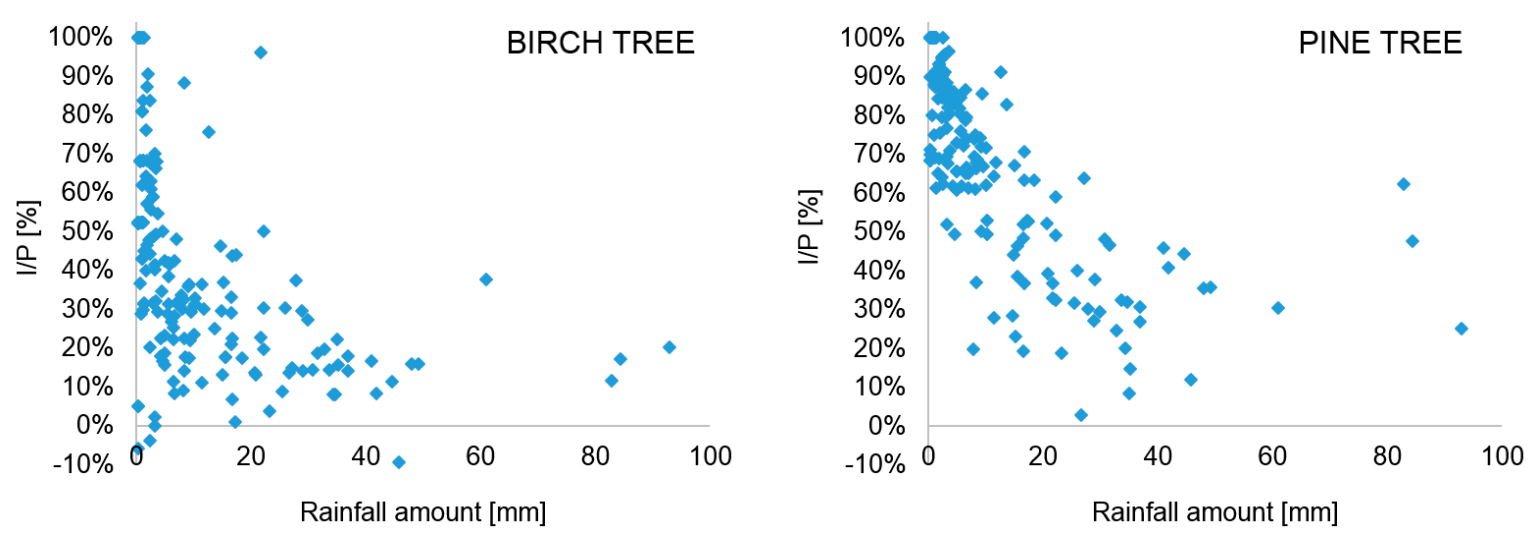

Figure 2. Ratio of rainfall interception to gross rainfall (I/P) for birch and pine trees.

\subsection{Multiple Correspondence Analysis (MCA)}

MCA was used to analyse the influence of different rainfall event characteristics on the rainfall interception ratio (I/P) by birch and pine trees in an urban area. Analysis was divided into three parts, for clearer presentation of the results on the diagrams. In all three cases, two dimensions were selected, expressing the highest statistical inertia. The dimensions have to be analysed separately, taking into account the sign and proximity of points. The zero axis of Dimension 1 is vertical and for Dimension 2 it is horizontal.

The first part of the analysis included the rainfall amount, intensity, and duration. The selected threshold values were $6 \mathrm{~mm}$ for rainfall amount (Pa6), $1.8 \mathrm{~mm} / \mathrm{h}$ for rainfall intensity (Pi1.8) and $4 \mathrm{~h}$ for rainfall duration (Pd4). The two dimensions expressed $75.7 \%$ of statistical inertia and both of them showed that the rainfall interception for pine and birch trees is most influenced by the rainfall amount (Figure 3). According to Dimension 1 of the performed MCA, the ratio of rainfall interception to rainfall amount for birch (IB36:0) and pine trees (IP75:0) was lower when the rainfall amount, intensity, and duration were higher than the threshold values (Pa6:1, Pi1.8:1 and Pd4:1). However, dimension 2 indicates different relationships (Figure 3). Similarly, in the case of the pine tree, the ratio of rainfall interception to gross rainfall decreases (IP75:0) during the events, delivering more than $6 \mathrm{~mm}$ of rainfall (Pa6:1) with intensities larger than $1.8 \mathrm{~mm} / \mathrm{h}$ (Pi1.8:1), regardless of the shorter duration (Pd4:0). However, in the case of the birch tree, the decrease in rainfall interception ratio (IB36:0) can 
be observed also during smaller (Pa6:0) and lighter (Pi1.8:0) events, with a duration of more than $4 \mathrm{~h}(\operatorname{Pd} 4: 1)$.

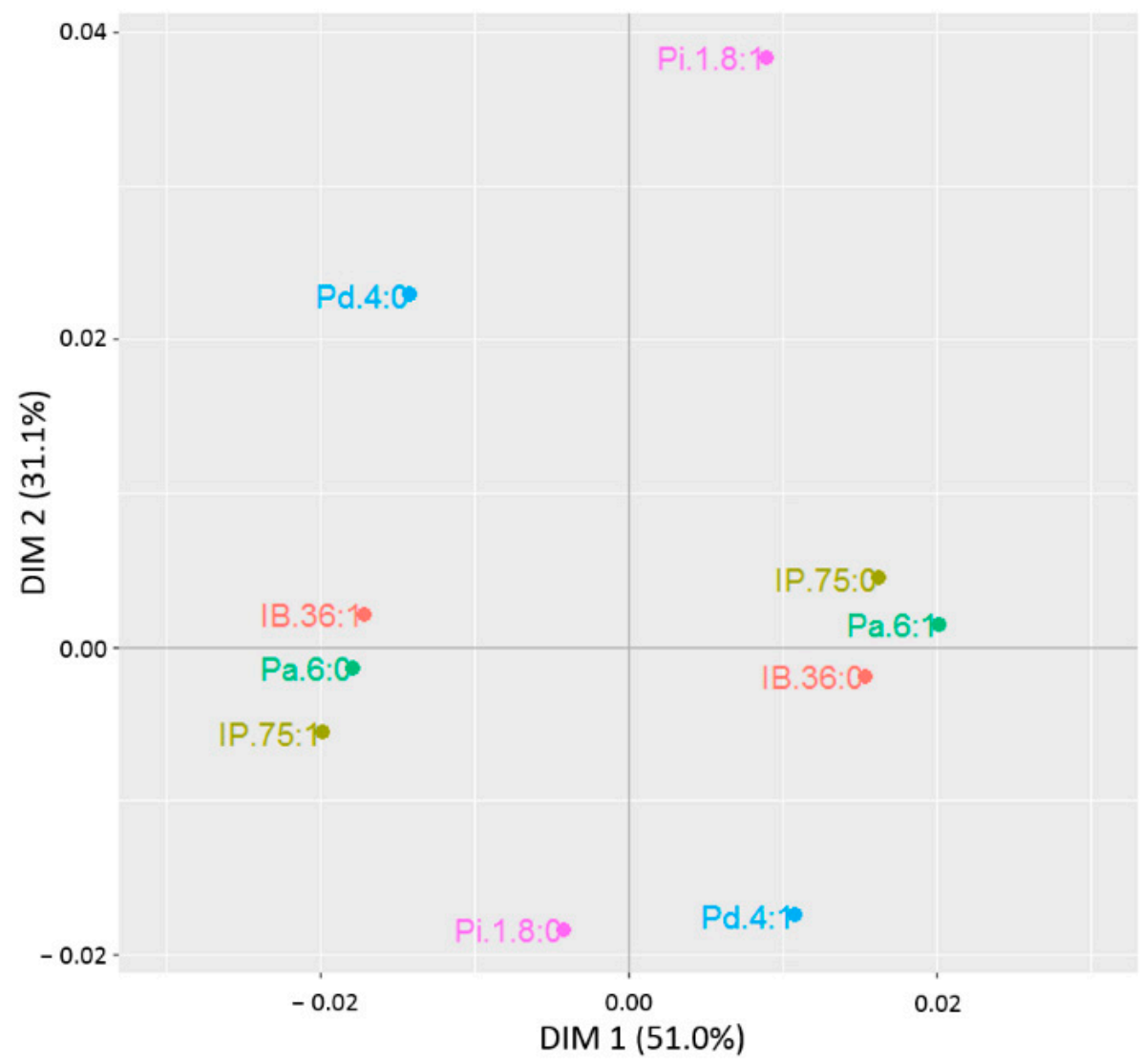

Figure 3. Diagram of MCA showing the influence of the rainfall amount (Pa), duration (Pd), and intensity (Pi) on rainfall interception by birch (IB) and pine (IP) trees.

The distinct influence of the rainfall amount on rainfall interception was often observed in various studies, connecting the decrease of the interception ratio $(\mathrm{I} / \mathrm{P})$ with the increase in rainfall amount $[12,14,22-24,30,36]$. As intercepted rainfall is assumed to evaporate from the canopies, this prominent influence of rainfall amount, considering the negligible influence of air humidity [14], can be explained by the splash droplet evaporation [53-55]. Larger rainfall amounts, with higher intensities, induce heavier splashes of raindrops upon reaching the canopy surface. Consequently, the evaporation of the so produced smaller drops is more efficient [53].

Selecting the threshold values of the variables, MCA was performed numerous times. When comparing the results of MCA, taking into account $10 \mathrm{~mm}$ of rainfall (median value) and $6 \mathrm{~mm}$ of rainfall (selected value), the points presenting rainfall interception and rainfall amount got closer together, expressing a larger interdependence. Zabret et al. [14] used the same data, and analysed them with regression trees and boosted regression trees. Regression trees for rainfall interception $(\mathrm{I} / \mathrm{P})$ showed the split value for the pine tree equal to a rainfall amount of $14.1 \mathrm{~mm}$, while rainfall amount was the first node variable for the birch tree at a value of $3.1 \mathrm{~mm}$. Comparing the threshold values for MCA, the chosen $6 \mathrm{~mm}$ better describes the initial value of interception expressed by the regression trees for birch and pine trees at the same time.

Wind characteristics were described by average event's wind speed (Ws) and direction (Wd). For wind speed, the threshold value of $1.3 \mathrm{~m} / \mathrm{s}$ was selected (Ws1.3), whereas wind direction was described by eight main directions (for example, south is WdS and north-west is WdNW). The two-dimension diagram captured $73.0 \%$ of statistical inertia. In this case, Dimensions 1 and 2 showed the very interesting influence of wind speed and direction (Figure 4). The decrease in the rainfall 
interception ratio of both tree species can be seen in each dimension observed in two scenarios (Figure 5). For wind speeds higher than $1.3 \mathrm{~m} / \mathrm{s}$ (Ws1.3:1), the wind corridor seems to appear from the south and south-west (WdS, WdSW) towards the north-east (WdNE). However, for lower wind speeds (Ws1.3:0), the corridor arises in a different direction, from the south and south-east (WdS, WdSE) towards the north-west (WdNW). Both directions are created on the edges of the nearby buildings and not in between them, as was assumed in the previous analysis [9]. However, the influence of the corridors seems to be minor, as the test observations of the rainfall on two locations at the study site (Figure 5) were performed. The Pearson correlation coefficient between the measured values from gauges was 0.99 and no statistically significant differences in the measured rainfall amount at the two locations were observed.

Wind speed was often recognized as an influencing parameter in other studies $[24,25,37,56]$. An increase of intercepted rainfall with wind speed was shown by Staelens et al. [21] and Šraj et al. [24], whereas a decrease in the interception ratio (increase of throughfall ratio) with wind speed was, for example, observed by Xiao et al. [12], Van Stan et al. [25] and Iida et al. [56]. Different responses were assigned to the different vegetation characteristics of the observed trees and their location [14]. However, further analysis with MCA offers a new insight into the relationship between interception and combination of wind conditions, also highlighting the wind direction.

As the rainfall event characteristics, the properties of raindrops were also included in the analysis, taking into account the number of raindrops (NrD) and their median volume diameter (MVD) as the descriptor of the raindrop size. The selected threshold value for MVD was $1.5 \mathrm{~mm}$ (MVD1.5), whereas the number of raindrops was described by three thresholds, dividing this variable into four classes (Table 3).

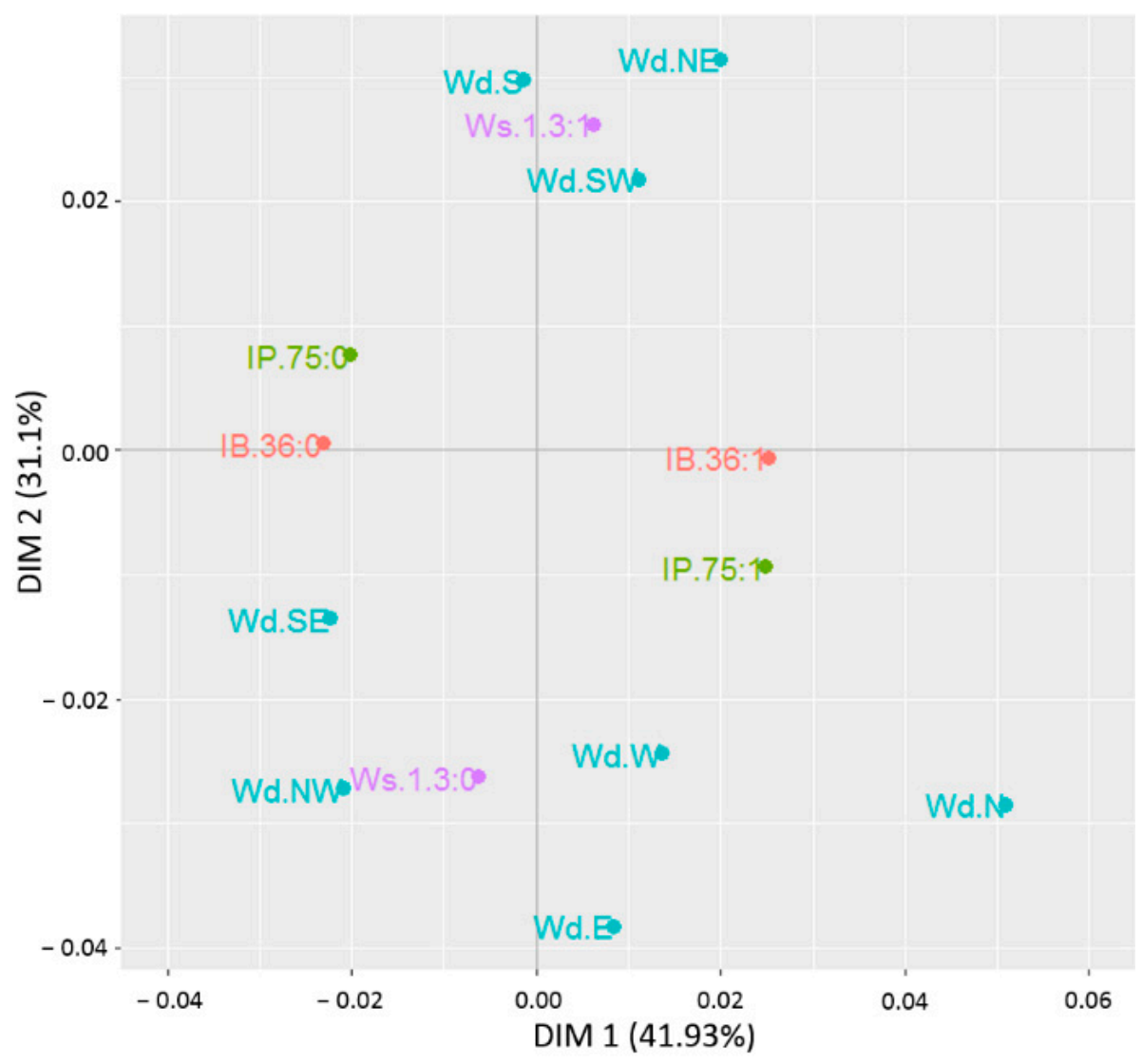

Figure 4. Diagram of MCA showing the influence of wind speed (Ws) and direction (Wd) on rainfall interception by birch (IB) and pine (IP) trees. 


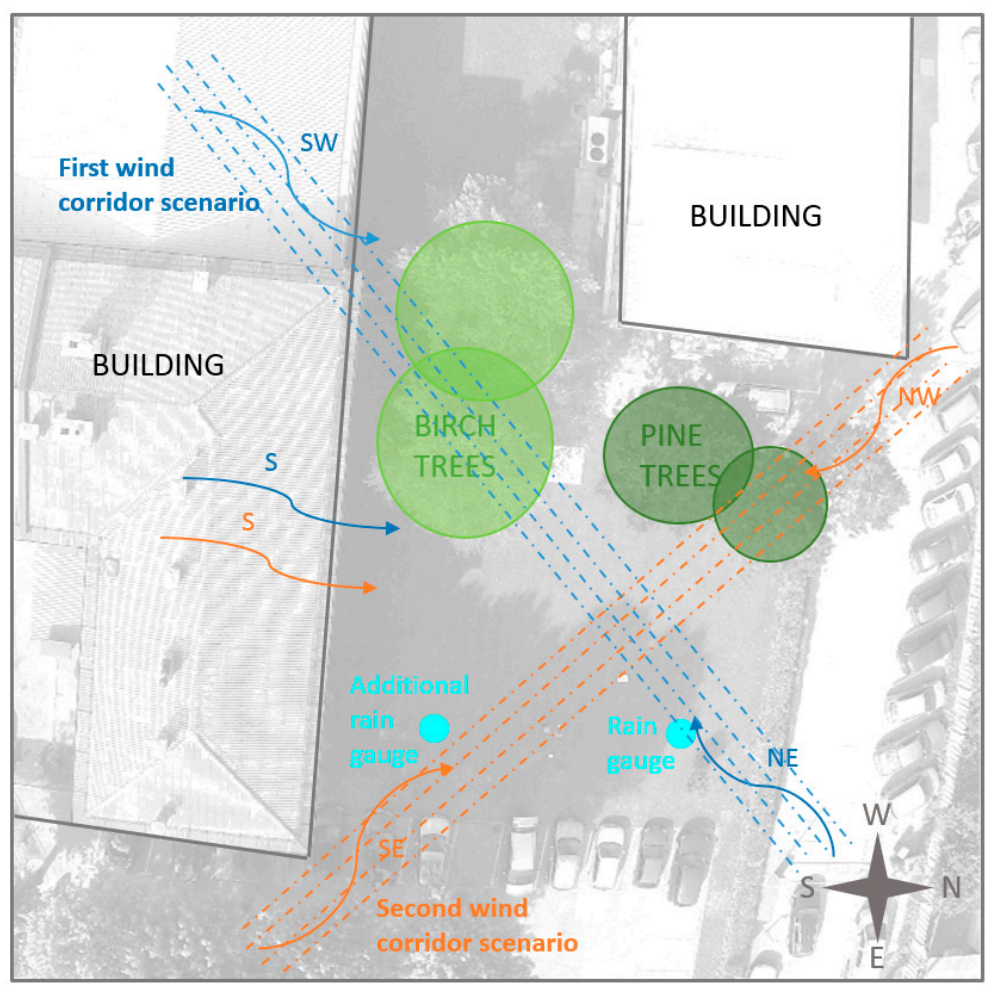

Figure 5. The directions of occasional wind corridors identified by MCA.

Table 3. Acronyms and threshold values for the variable "number of drops $(\mathrm{NrD})$ ".

\begin{tabular}{ccccc}
\hline Acronym & NrD10:0 & NrD10-50 & NrD50-100 & NrD100:1 \\
\hline Number of Raindrops Per Class & $<10,000$ & $10,000-50,000$ & $50,001-100,000$ & $>100,000$ \\
\hline
\end{tabular}

The two-dimension MCA covered $82.1 \%$ of statistical inertia and, in both directions characterized the number of raindrops as the more influential variable (Figure 6). The results in Dimension 1 show a decrease in the rainfall interception ratio (IB36:0 and IP75:0) for larger raindrops (MVD1.5:1) and their number of more than 50,000. According to Dimension 2, the response of the tree species may differ according to the size of the raindrops. Interception ratio $(\mathrm{I} / \mathrm{P})$ by the birch tree decreases, regardless of the large number of small raindrops (MVD1.5:0), and increases for the small number (NrD10:0) of large raindrops (MVD1.5:1). However, in the case of the pine tree, the small number (NrD10:0) of large raindrops (MVD1.5:1) decreased the interception ratio, whereas it increased it for smaller raindrops (MVD1.5:0) regardless of their number.

A different response of the tree species to the drop size distribution was also observed in other studies $[3,27,31,57]$. When analysing throughfall dynamics at the event level under the observed trees [3], throughfall under the pine tree immediately increased with larger and faster raindrops, which corresponds to the increase in pine's interception ratio (I/P) with smaller raindrops (MVD). These results are supported also by the studies of Calder [58] and Hall [59]. However, birch tree interception analysis using regression trees suggested the opposite, as smaller raindrops decrease the rainfall interception ratio of the birch tree [14].

The number of raindrops was also recognized as a variable with a high influence in previous studies [14,27]. However, the rainfall amount and the number of drops are strongly correlated with a correlation coefficient of 0.82 . Zabret et al. [14] have taken into account this relationship and concluded that these two variables influence rainfall interception differently, probably due to the raindrop size. This assumption was also confirmed with the presented MCA. Rainfall interception ratio to gross rainfall decreases with an increasing rainfall amount (Figure 3), but the influence of the number of raindrops highly depends on MVD (Figure 6). 


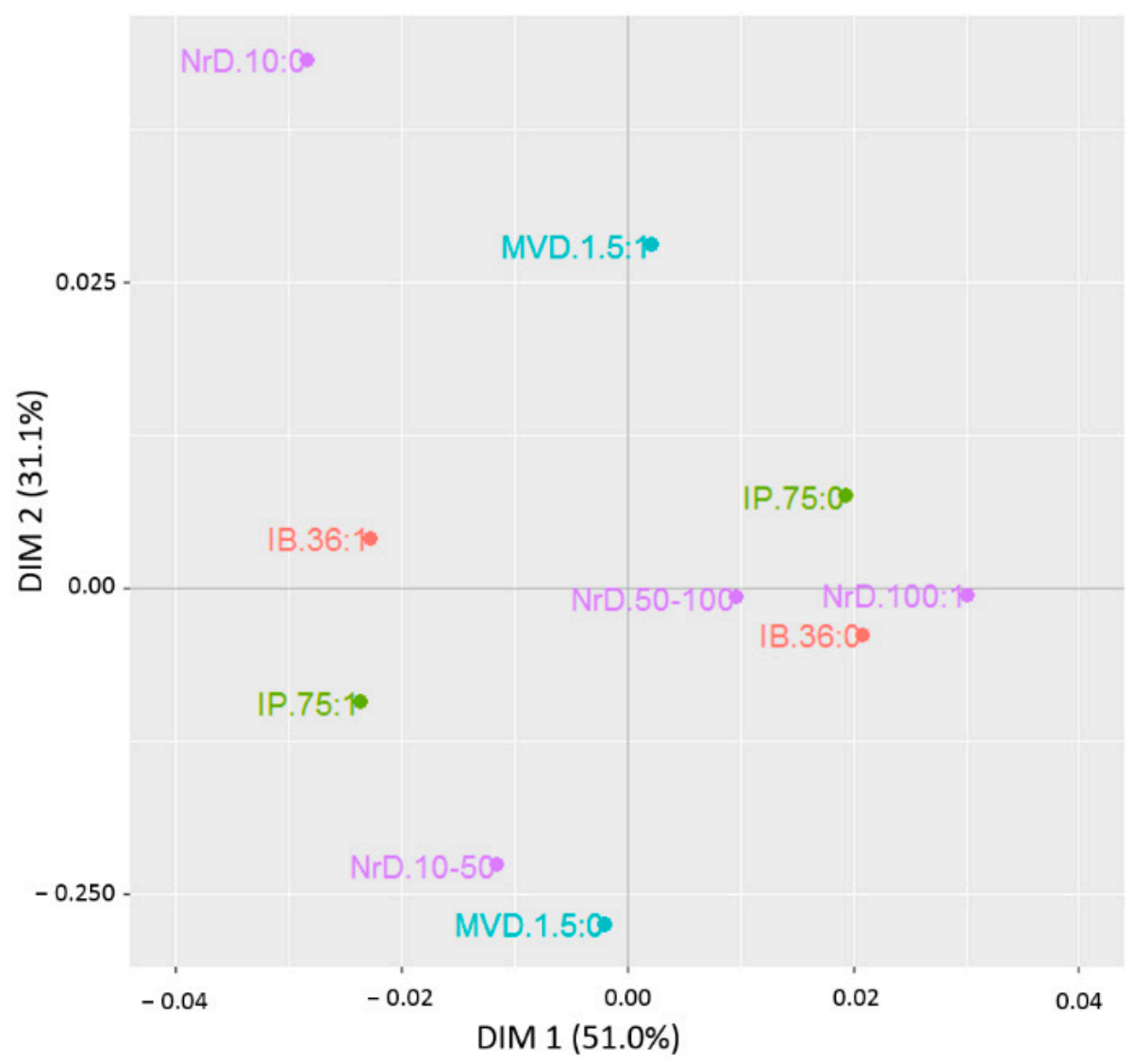

Figure 6. Diagram of MCA showing the influence of the median volume diameter (MVD) and the number of raindrops $(\mathrm{NrD})$ on rainfall interception by birch $(\mathrm{IB})$ and pine $(\mathrm{IP})$ trees.

\section{Conclusions}

Rainfall interception by deciduous (birch) and coniferous (pine) tree species, located in an urban area, in accordance to influencing meteorological variables, was analysed using the multiple correspondence analysis (MCA). The variables describing rainfall event characteristics were rainfall amount, duration and intensity, wind speed and direction, and raindrop properties (drop size described by MVD and the number of raindrops). MCA confirmed some of the well-known and expected relationships between rainfall interception and meteorological variables, validated the results of previous analyses from the same study plot and indicated some new insights.

Once again, the MCA stressed the influence of the rainfall amount and the number of raindrops on rainfall interception ratio (I/P). A larger rainfall amount and more raindrops decrease the rainfall interception to gross rainfall ratio. However, the combined influence of other event characteristics can result in an interception ratio increase. The difference is evident, especially in the case of the drop size spectrum, where the vegetation properties also have a significant role. Additionally, MCA using the threshold values simplifies the presentation of the data and so points to new connections, as in the case of wind conditions or drop size distribution.

The presented analysis is an example of the application of MCA in hydrology. We demonstrated that upgrading the statistical analysis of large databases, collected during long periods of measurements, with additional statistical methods from other research fields, is useful. It can support the existing knowledge and predictions based on simpler data analyses, and offer a new insight into natural process.

Author Contributions: K.Z. and M.Š. drafted the manuscript and determined the aims of the research; K.Z. collected and analysed the data; K.Z. and M.Š. wrote the paper and prepared the revisions.

Funding: This research received no external funding. 
Conflicts of Interest: The authors declare no conflict of interest.

\section{References}

1. Chang, S.C.; Matzner, E. The effect of beech stemflow on spatial pattern of soil solution chemistry and seepage fluxes in a mixed beech/oak stand. Hydrol. Process. 2000, 14, 135-144. [CrossRef]

2. Friesen, J.; Van Stan, J.T. Early European Observations of Precipitation Partitioning by Vegetation: A Synthesis and Evaluation of 19th Century Findings. Geosciences 2019, 9, 423. [CrossRef]

3. Zabret, K.; Rakovec, J.; Mikoš, M.; Šraj, M. Influence of raindrop size distribution on throughfall dynamics under pine and birch trees at the rainfall event level. Atmosphere 2017, 8, 240. [CrossRef]

4. Levia, D.F.; Nanko, K.; Amasaki, H.; Giambelluca, T.W.; Hotta, N.; Iida, S.; Mudd, R.G.; Nullet, M.A.; Sakai, N.; Shinohara, Y.; et al. Throughfall partitioning by trees. Hydrol. Process. 2019, 33, 1698-1708. [CrossRef]

5. Levia, D.F.; Frost, E.E. A review and evaluation of stemflow literature in the hydrologic and biogeochemical cycles of forested and agricultural ecosystems. J. Hydrol. 2003, 274, 1-29. [CrossRef]

6. Guevara-Escobar, A.; Gonzalez-Sosa, E.; Veliz-Chavez, C.; Ventura-Ramos, E.; Ramos-Salinas, M. Rainfall interception and distribution patterns of gross precipitation around an isolated Ficus benjamina tree in an urban area. J. Hydrol. 2007, 333, 532-541. [CrossRef]

7. Livesley, S.J.; Baudinette, B.; Glover, D. Rainfall interception and stemflow by eucalypt street trees-The impacts of canopy density and bark type. Urban For. Urban Green. 2014, 13, 192-197. [CrossRef]

8. Yang, B.; Lee, D.K.; Heo, H.K.; Biging, G. The effects of tree characteristics on rainfall interception in urban areas. Landsc. Ecol. Eng. 2019, 15, 289-296. [CrossRef]

9. Zabret, K.; Šraj, M. Rainfall Interception by Urban Trees and Their Impact on Potential Surface Runoff. Clean Soil Air Water 2019, 47, 1800327. [CrossRef]

10. Wang, M.; Zhang, D.Q.; Su, J.; Trzcinski, A.P.; Dong, J.W.; Tan, S.K. Future Scenarios Modeling of Urban Stormwater Management Response to Impacts of Climate Change and Urbanization. Clean Soil Air Water 2017, 45, 1700111. [CrossRef]

11. Rahman, M.A.; Moser, A.; Anderson, M.; Zhang, C.; Rötzer, T.; Pauleit, S. Comparing the infiltration potentials of soils beneath the canopies of two contrasting urban tree species. Urban For. Urban Green. 2019, 38, 22-32. [CrossRef]

12. Xiao, Q.; McPherson, E.G.; Ustin, S.L.; Grismer, M.E.; Simpson, J.R. Winter rainfall interception by two mature open-grown trees in Davis, California. Hydrol. Process. 2000, 14, 763-784. [CrossRef]

13. Asadian, Y.; Weiler, M. A New Approach in Measuring Rainfall Interception by Urban Trees in Coastal British Columbia. Water Qual. Res. J. Can. 2009, 44, 16-25. [CrossRef]

14. Zabret, K.; Rakovec, J.; Šraj, M. Influence of meteorological variables on rainfall partitioning for deciduous and coniferous tree species in urban area. J. Hydrol. 2018, 558, 29-41. [CrossRef]

15. Armson, D.; Stringer, P.; Ennos, A.R. The effect of street trees and amenity grass on urban surface water runoff in Manchester, UK. Urban For. Urban Green. 2013, 12, 282-286. [CrossRef]

16. Wang, J.; Endreny, T.A.; Nowak, D.J. Mechanistic Simulation of Tree Effects in an Urban Water Balance Model. JAWRA 2008, 44, 75-85. [CrossRef]

17. Sjöman, J.D.; Gill, S.E. Residential runoff-The role of spatial density and surface cover, with a case study in the Höjeå river catchment, southern Sweden. Urban For. Urban Green. 2014, 13, 304-314. [CrossRef]

18. Huang, J.Y.; Black, T.A.; Jassal, R.S.; Les Lavkulich, L.M. Modelling rainfall interception by urban trees. Water Qual. Res. J. Can. 2017, 42. [CrossRef]

19. Smets, V.; Wirion, C.; Bauwens, W.; Hermy, M.; Somers, B.; Verbeiren, B. The importance of city trees for reducing net rainfall: Comparing measurements and simulations. Hydrol. Earth Syst. Sci. 2019, 23, 3865-3884. [CrossRef]

20. Crockford, R.H.; Richardson, D.P. Partitioning of rainfall into throughfall, stemflow and interception: Effect of forest type, ground cover and climate. Hydrol. Process. 2000, 14, 2903-2920. [CrossRef]

21. Staelens, J.; De Schrijver, A.; Verheyen, K.; Verhoest, N.E.C. Rainfall partitioning into throughfall, stemflow, and interception within a single beech (Fagus sylvatica L.) canopy: Influence of foliation, rain event characteristics, and meteorology. Hydrol. Process. 2008, 22, 33-45. [CrossRef] 
22. Zabret, K.; Šraj, M. Spatial variability of throughfall under single birch and pine tree canopies. Acta Hydrotech. 2018, 31, 1-20. [CrossRef]

23. Magliano, P.N.; Whitworth-Hulse, J.I.; Florio, E.L.; Aguirre, E.C.; Blanco, J.L. Interception loss, throughfall and stemflow by Larrea divaricata: The role of rainfall characteristics and plant morphological attributes. Ecol. Res. 2019, 34, 753-764. [CrossRef]

24. Šraj, M.; Brilly, M.; Mikoš, M. Rainfall interception by two deciduous Mediterranean forests of contrasting stature in Slovenia. Agric. For. Meteorol. 2008, 148, 121-134. [CrossRef]

25. Van Stan, J.T.; Van Stan, J.H.; Levia, D.F. Meteorological influences on stemflow generation across diameter size classes of two morphologically distinct deciduous species. Int. J. Biometeorol. 2014, 58, 2059-2069. [CrossRef]

26. Bezak, N.; Zabret, K.; Šraj, M. Application of Copula Functions for Rainfall Interception Modelling. Water 2018, 10, 995. [CrossRef]

27. Nanko, K.; Hotta, N.; Suzuki, M. Evaluating the influence of canopy species and meteorological factors on throughfall drop size distribution. J. Hydrol. 2006, 329, 422-431. [CrossRef]

28. Barbier, S.; Balandier, P.; Gosselin, F. Influence of several tree traits on rainfall partitioning in temperate and boreal forests: A review. Ann. For. Sci. 2009, 66, 602. [CrossRef]

29. Zabret, K. The influence of tree characteristics on rainfall interception. Acta Hydrotech. 2013, 26, 99-116. (In Slovenian)

30. Siegert, C.M.; Levia, D.F. Seasonal and meteorological effects on differential stemflow funneling ratios for two deciduous tree species. J. Hydrol. 2014, 519, 446-454. [CrossRef]

31. Holder, C.D.; Gibbes, C. Influence of leaf and canopy characteristics on rainfall interception and urban hydrology. Hydrol. Sci. J. 2016, 26, 182-190. [CrossRef]

32. Fleischbein, K.; Wilcke, W.; Goller, R.; Boy, J.; Valarezo, C.; Zech, W.; Knoblich, K. Rainfall interception in a lower montane forest in Ecuador: Effects of canopy properties. Hydrol. Process. 2005, 19, 1355-1371. [CrossRef]

33. Dohnal, M.; Černy, T.; Votrubova, J.; Tesar, M. Rainfall interception and spatial variability of throughfall in spruce stand. J. Hydrol. Hydromech. 2014, 62, 277-284. [CrossRef]

34. Schooling, J.T.; Carlyle-Moses, D.E. The influence of rainfall depth class and deciduous tree traits on stemflow production in an urban park. Urban Ecosyst. 2015, 18, 1261-1284. [CrossRef]

35. Honda, E.A.; Mendonça, A.H.; Durigan, G. Factors affecting the stemflow of trees in the Brazilian Cerrado. Ecohydrology 2014, 8, 1351-1362. [CrossRef]

36. Nytch, C.J.; Meléndez-Ackerman, E.J.; Pérez, M.E.; Ortiz-Zayas, J.R. Rainfall interception by six urban trees in San Juan, Puerto Rico. Urban Ecosyst. 2019, 22, 103. [CrossRef]

37. Nanko, K.; Hudson, S.A.; Levia, D.F. Differences in throughfall drop size distributions in the presence and absence of foliage. Hydrol. Sci. J. 2016, 61, 620-627. [CrossRef]

38. Tanaka, N.; Levia, D.; Igarashi, Y.; Yoshifuji, N.; Tanaka, K.; Tantasirin, C.; Nanko, K.; Suzuki, M.; Kumagai, T. What factors are most influential in governing stemflow production from plantation-grown teak trees? J. Hydrol. 2017, 544, 10-20. [CrossRef]

39. Zhang, Y.F.; Wang, X.P.; Pan, Y.X.; Hu, R. Relative contribution of biotic and abiotic factors to stemflow production and funneling efficiency: A long-term field study on a xerophytic shrub species in Tengger Desert of northern China. Agric. For. Meteorol. 2020, 280, 107781. [CrossRef]

40. Van Stan, J.T.; Gay, T.E.; Lewis, E.S. Use of multiple correspondence analysis (MCA) to identify interactive meteorological conditions affecting relative throughfall. J. Hydrol. 2016, 533, 452-460. [CrossRef]

41. Richards, G.; van der Ark, L.A. Dimensions of cultural consumption among tourists: Multiple correspondence analysis. Tour. Manag. 2013, 37, 71-76. [CrossRef]

42. Husson, F.; Josse, J. Multiple Correspondence Analysis. In The Visualization and Verbalization of Data; Greenacre et Blasius; CRC/PRESSE: Boca Raton, FL, USA, 2014.

43. Ali, F.; Dissanayake, D.; Bell, M.; Darrow, M. Investigating car users' attitudes to climate change using multiple correspondence analysis. J. Transp. Geogr. 2018, 72, 237-247. [CrossRef]

44. Dussault, M.C.; Smith, M.; Hanson, I. Evaluation of trauma patterns in blast injuries using multiple correspondence analysis. Forensic Sci. Int. 2016, 267, 66-72. [CrossRef] [PubMed] 
45. Han, L.; Benseler, S.M.; Tyrrell, P.N. Cluster and Multiple Correspondence Analyses in Rheumatology: Paths to Uncovering Relationships in a Sea of Data. Rheum. Dis. Clin. N. Am. 2018, 44, 349-360. [CrossRef] [PubMed]

46. Mancini, R.; Pattaro, G.; Diodoro, M.G.; Sperduti, I.; Garufi, C.; Stigliano, V.; Perri, P.; Grazi, G.L.; Cosimelli, M. Tumor Regression Grade after Neoadjuvant Chemoradiation and Surgery for Low Rectal Cancer Evaluated by Multiple Correspondence Analysis: Ten Years as Minimum Follow-up. Clin. Colorectal Cancer 2018, 17, e13-e19. [CrossRef]

47. ARSO. Available online: http://www.meteo.si/met/sl/archive/ (accessed on 11 November 2019).

48. Pérez-Harguindeguy, N.; Díaz, S.; Garnier, E.; Lavorel, S.; Poorter, H.; Jaureguiberry, P.; Bret-Harte, M.S.; Cornwell, W.K.; Craine, J.M.; Gurvich, D.E.; et al. New handbook for standardized measurement of plant functional traits worldwide. Aust. J. Bot. 2013, 61, 167-234. [CrossRef]

49. IGI Global. Available online: https://www.igi-global.com/dictionary/fundamentals-of-electrostatic-spraying/ 49548 (accessed on 20 November 2019).

50. Van Stan, J.T.; Siegert, C.M.; Levia, D.F.; Scheick, C.E. Effects of wind-driven rainfall on interception and stemflow generation between two codominant tree species with differing crown characteristics. Agric. For. Meteorol. 2016, 151, 1277-1286. [CrossRef]

51. Ripley, B.; Venables, B.; Bates, D.M.; Hornik, K.; Gebhardt, A.; Firth, D. Package “Mass". Available online: https://cran.r-project.org/web/packages/MASS/MASS.pdf (accessed on 7 November 2019).

52. R Core Team. R: A Language and Environment for Statistical Computing; R Foundation for Statistical Computing: Vienna, Austria, 2018. Available online: http://www.R-project.org/ (accessed on 7 November 2018).

53. Murakami, S. A proposal for a new forest canopy interception mechanism: Splash droplet evaporation. J. Hydrol. 2006, 319, 72-82. [CrossRef]

54. Dunkerley, D.L. Evaporation of impact water droplets in interception processes: Historical precedence of the hypothesis and a brief literature overview. J. Hydrol. 2009, 376, 599-604. [CrossRef]

55. Saito, T.; Matsuda, H.; Komatsu, M.; Xiang, Y.; Takahashi, A.; Shinohara, Y.; Otsuki, K. Forest canopy interception loss exceeds wet canopy evaporation in Japanese cypress (Hinoki) and Japanese cedar (Sugi) plantations. J. Hydrol. 2013, 507, 287-299. [CrossRef]

56. Iida, S.; Levia, D.F.; Shimizu, A.; Shimizu, T.; Tamai, K.; Nobuhiro, T.; Kabeya, N.; Noguchi, S.; Sawano, S.; Araki, M. Intrastorm scale rainfall interception dynamics in a mature coniferous forest stand. J. Hydrol. 2017, 548, 770-783. [CrossRef]

57. Lüpke, M.; Leuchner, M.; Levia, D.; Nanko, K.; Iida, S.; Menzel, A. Characterization of differential throughfall drop size distributions beneath European beech and Norway spruce. Hydrol. Process. 2019, 33, 3391-3406. [CrossRef]

58. Calder, I.R. Dependence of rainfall interception on drop size: 1. Development of the two-layer stochastic model. J. Hydrol. 1996, 185, 363-378. [CrossRef]

59. Hall, R.L. Interception loss as a function of rainfall and forest types: Stochastic modelling for tropical canopies revisited. J. Hydrol. 2003, 280, 1-12. [CrossRef]

(C) 2019 by the authors. Licensee MDPI, Basel, Switzerland. This article is an open access article distributed under the terms and conditions of the Creative Commons Attribution (CC BY) license (http://creativecommons.org/licenses/by/4.0/). 